\title{
A review of canola meal as an alternative feed ingredient for ducks
}

\author{
Samiru Sudharaka Wickramasuriya ${ }^{1 \dagger}$, Young-Joo $\mathrm{Yi}^{2 \dagger}$, Jaehong Yoo ${ }^{1}$, Nam Kyu Kang ${ }^{1}$ and Jung Min Heo ${ }^{1 *}$
}

\begin{abstract}
This review provides an overview of the published data on the canola meal and its suitability for duck as an alternative plant-origin protein source to soybean meal. Canola meal is a legume origin protein source containing comparable amino acid profile to soybean meal and rich in essential minerals and vitamins. Nonetheless, it is known to contain less in energy content than soybean meal. Factors like field conditions and processing methods creates compositional variations among canola meal. Presence of anti-nutritional factors such as phenolic substances, phytate and glucosinolates which are known to reduce growth performance in livestock animals, are the major drawbacks for canola meal to be a competitive plant-origin protein source in the feed industry. This review is focused to address i) nutritional characteristics and feeding value of canola meal for ducks and ii) impacts of feeding canola meal on performances of ducks.

Keywords: Anti-nutritional factors, Canola meal, Ducks, Feeds
\end{abstract}

\section{Introduction}

Due to increasing diet cost in animal production industry, it has been becoming important to explore alternative feed ingredients for cost effective animal production. The use of less expensive protein and amino acid source is one of the ways to reduce the feed costs in the area of animal production. Concurrently, the effect of feed ingredients on growth performance of host animals should be carefully accounted for proper evaluation of an alternative ingredient [1].

Soybean meal has long been used as a reference plantorigin protein source in the animal feed industry. However, the cost of using soybean meal can increase cost of diet, and in turn many poultry producers are searching for alternative sources of supplementary protein source that are cost effective $[2,3]$.

Canola is a new variety of rapeseed which developed using plant breeding techniques to reduce the toxic glucosinolate content [4]. Canola meal is an oil seed meal and contains high concentration of protein and a wellbalanced amino acid profile [5]. In addition, essential minerals and vitamins, such as choline, biotin, folic acid, niacin, riboflavin and thiamin are available in canola

\footnotetext{
* Correspondence: jmheo@cnu.ac.kr

${ }^{\dagger}$ Equal contributors

'Division of Animal and Dairy Science, Chungnam National University,

Daejeon 305-764, Republic of Korea

Full list of author information is available at the end of the article
}

meal [6-8]. Nonetheless with compared to soybean meal, inclusion of canola meal in diets for birds have been limited due to less-protein, less-energy and higher dietary fiber $[6,9]$. The development of low erucic acid and low glucosinolate cultivars of canola has resulted in increased usage of canola meal in poultry rations $[10,11]$. Only a few studies demonstrated that duck utilize energy in canola meal more efficiently than chickens [11-14], however comparable amino acid digestibility was found in both ducks and chickens [15].

Rearing ducks for the production purpose (i.e., eggs and meat) are an advantageous activity in livestock industry as they are rather easier and cheaper to grow than chickens. Utilization of canola meal as an alternative plant protein source for duck is having a great value in terms of cost minimization [16].

A couple of review articles $[6,17]$ have attempted to elaborate factors effecting nutritive value of canola meal. Nonetheless, canola meal on ducks was not focused nor evaluated. Further, published data pertaining to the nutritive values of canola meal for ducks are limited. This review, therefore, will be focused on i) nutritional characteristics and feeding value of canola meal for ducks, and ii) impact of feeding canola meal on performances of ducks. 


\section{Review}

\section{Duck production}

Duck production is very popular and has a great demand in many parts of the world [18]. Meat products of ducks were the third highest poultry meat production [19]. Duck meat production was expanded by 1.3 million tons from 2000 to 2011 in worldwide and yet, the trend is continuing. Asia is the leading duck producing region compare to other regions [20]. With compared to chicken meat, duck meat is having distinctive characteristics as a red meat [18]. With the increasing demand many duck meat retail cuts become more available for the diet conscious customers [18]. Beside from the duck meat, egg and down feathers are another two main products that have great demand [21].

Profitability of the duck production can be increased by adapting the unconventional feed to the diet formulation which reduces the production cost, especially by utilizing low cost plant protein over animal protein [16].

\section{Chemical and nutritional composition Proximate composition}

Canola meal is considered as a source of vegetable protein for livestock industry. Considered principal nutrient components of canola meal include protein, carbohydrates, crude fiber and ash along with residual oil which is not removed through the oil extraction process (Table 1). Although canola meal commonly used as a protein source in animal diets, it contains lower protein (36\%), and available energy (2,000 kcal/kg AME) but higher fiber (12\%) content compared with soybean meal (7\%) [22].

Proximate composition of canola meal varies due to cultivars, environment conditions during growing and harvesting periods and crushing conditions [28]. For example, dry seasonal conditions create lower oil content and higher level of protein content [24]. Furthermore, canola meal quality is influenced by the type of oil extraction process (i.e., expeller- and solvent-extraction) [29]. Level of heating duration contributes to degradation of heat sensitive amino acids such as lysine [23]. Expeller-pressed canola meal contains more residual oils than solvent-extracted canola meal [24, 30].

Dietary protein content in canola meal can be highly influenced by the protein content of canola seeds [24]. Additionally, it relates with carbohydrate fraction, oil fractions along with the oil extraction efficiency from seed and changes in moisture content during the processing [24]. According to Canadian Canola Council, the minimum crude protein guarantee for Canadian canola meal is 36 \% (8.5\% moisture basis). However, actual protein content is usually 36-39\% (Table 1). It depends on variation in canola seed composition yearly due to growing and harvest conditions [23].

Although protein content depends on growing conditions of canola, protein quality is directly related with
Table 1 Chemical composition of canola meal (as fed basis)

\begin{tabular}{|c|c|c|c|}
\hline Component & Solvent form & Expeller form & Reference \\
\hline Dry matter, \% & 88.0 & 82.9 & [23] \\
\hline \multirow[t]{6}{*}{ Crude protein, \% } & 37.3 & 36.3 & [24] \\
\hline & 36.0 & 36.3 & [23] \\
\hline & 37.3 & 34.5 & [15] \\
\hline & 34.0 & 32.0 & [25] \\
\hline & - & 36.3 & [26] \\
\hline & 34.0 & - & [27] \\
\hline \multirow[t]{5}{*}{ Crude fiber, \% } & 9.85 & 10.6 & [24] \\
\hline & 12.0 & 10.6 & [23] \\
\hline & 15.0 & 14.0 & [25] \\
\hline & - & 6.9 & [26] \\
\hline & 9.3 & - & [27] \\
\hline \multirow[t]{4}{*}{ Ash, \% } & 7.3 & 6.3 & [24] \\
\hline & 6.1 & 6.3 & [23] \\
\hline & - & 6.9 & [26] \\
\hline & 6.8 & - & [27] \\
\hline \multirow[t]{3}{*}{ Fat, \% } & 3.4 & 11.1 & [24] \\
\hline & 3.5 & 11.1 & [23] \\
\hline & 3.5 & & {$[27]$} \\
\hline \multirow[t]{4}{*}{ Moisture, \% } & 10.7 & 7.1 & [24] \\
\hline & 12 & 11 & {$[25]$} \\
\hline & - & 5.6 & {$[26]$} \\
\hline & 11.1 & - & {$[27]$} \\
\hline
\end{tabular}

Dashes indicate that no data were available

processing method [31, 32]. In particular, reduction in protein digestibility and protein quality are influenced by heat treatments, use for oil extraction and subsequent desolventizing and toasting of canola seed [32]. In addition, some $[33,34]$ demonstrated that soluble protein content decreased during the heat-treatment, and also resulted in lowering protein depositon, ileal-digestible lysine retention and growth performance of host animals. Protein quality of canola meal for ducks is scantly documented and aforementioned findings are based on other monogastrics.

Canola meal also contains complex carbohydrates fractions [23] (Table 2). Fiber components of canola meal include lignin with associated polyphenols (8\%), cellulose (4-6 \%) and non-cellulosic polysaccharides (13-16\%) which consist predominantly of pectic substances [35]. Other important components include oligosaccharides (2.5\%), glycoprotein (5\%; i.e., arabinogalactan-protein, cell wall protein), phytate (3.3\%), minerals associated with the fiber fraction (1\%) and gums (4\%). Similar to other nutrients, variability may be caused by several factors including method of analysis, genetic differences, harvest management and environmental conditions during the growing stage [6]. For example, yellow-seed Brassica 
Table 2 Carbohydrate components of canola meal

\begin{tabular}{llllll}
\hline Component & \multicolumn{3}{l}{ Value $(\mathrm{g} / \mathrm{kg})$} & & \\
\cline { 2 - 7 } & {$[6]^{\mathrm{a}}$} & {$[23]^{\mathrm{b}}$} & {$[17]^{\mathrm{c}}$} & {$[25]^{\mathrm{c}}$} & {$[37]^{\mathrm{b}}$} \\
\hline Starch & 25 & 51 & 24 & 52 & - \\
Sugars & - & 67 & - & 80 & - \\
Sucrose & 77 & 62 & 60 & - & - \\
Fructose + glucose & - & 05 & - & - & - \\
Cellulose & 49 & 45 & - & 46 & 46 \\
Oligosaccharides & 25 & 22 & 20 & 23 & 23 \\
Non-starch polysaccharides (NSP) & 179 & 157 & 180 & 161 & 161 \\
Soluble NSP & 15 & 14 & - & 14 & 14 \\
Insoluble NSP & 164 & 144 & - & 147 & 147 \\
Crude fiber & 146 & 117 & 116 & 120 & 120 \\
Acid detergent fiber & 198 & 168 & 182 & 172 & 172 \\
Acid detergent lignin & - & 51 & - & - & \\
Neutral detergent lignin & - & 207 & - & - & \\
Total dietary fiber & 331 & 323 & 317 & 330 & 330 \\
\hline
\end{tabular}

Dashes indicate that no data were available

${ }^{a}$ Oil-free, dry matter

${ }^{\mathrm{b}} 12 \%$ moisture basis

${ }^{c} 10 \%$ moisture basis

campestris had a lower percentage seed coat (hull) than brown seed types [36]. Although yellow hulls evident that lower fiber content, yellow seed embryos contains high measures of fiber over the brown seeds [6].

\section{Nutritional content and minerals}

Canola meal is considered as a quality source of essential minerals (Table 3). In addition, some documented that it is a relatively good source of essential minerals compared to other vegetable-origin oilseeds [23]. Similarly, a couple of studies $[1,38]$ determined that canola meal contains higher calcium and phosphorus contents than soybean meal. Although $65 \%$ of the phosphorus in canola meal is in the phytate form which is not available for monogastric animals, it is still a better source of calcium and phosphorus compared to soybean meal $[1,38]$. Documented data pertaining to mineral availability of canola meal on duck were scare. However, feeding canola meal along with in-feed phytase would improve availability of minerals for monogastric animals [39]. In addition, canola meal appears to be a quility source of selenium relative to other oilseed meals [37].

In terms of vitamin content, canola meal has a greater vitamin compared to soybean meal (Table 4) but there is limited information available on vitamins composition of canola meal. It was reported that canola meal contains greater amounts of B vitamins such as biotin, folic acid, niacin, riboflavin and thiamin compared with soybean meal [4].
Table 3 Mineral composition of the canola meal and soybean meal

\begin{tabular}{|c|c|c|c|c|c|c|}
\hline \multirow[t]{2}{*}{ Mineral } & \multicolumn{4}{|c|}{ Canola meal } & \multicolumn{2}{|c|}{ Soybean meal } \\
\hline & {$[24]^{a}$} & {$[28]^{\mathrm{b}}$} & {$[17]^{\mathrm{C}}$} & $\overline{[40]^{d}}$ & $\overline{[17]^{c}}$ & {$[40]^{\mathrm{d}}$} \\
\hline Calcium, \% & 0.56 & 0.70 & 0.67 & 0.68 & 0.33 & 0.27 \\
\hline Phosphorus, \% & 0.96 & 1.13 & 1.02 & 1.17 & 0.66 & 0.62 \\
\hline Phytate phosphorus, \% & 0.83 & - & 0.64 & - & 0.38 & - \\
\hline Sodium, \% & - & - & 0.08 & - & 0.01 & - \\
\hline Chlorine, \% & 0.10 & - & 0.10 & - & 0.05 & 0.05 \\
\hline Potassium, \% & 1.26 & 1.35 & 1.17 & 1.29 & 2.00 & - \\
\hline Sulphur, \% & 0.62 & 0.94 & 0.65 & - & 0.44 & - \\
\hline Magnesium, \% & 0.47 & 0.57 & 0.56 & 0.64 & 0.28 & - \\
\hline Copper, mg/kg & 3.9 & 6.34 & - & 10 & - & 15 \\
\hline Iron, mg/kg & 138 & 157 & - & 159 & - & 170 \\
\hline Manganese, mg/kg & 52 & 54.7 & - & 54 & - & 43 \\
\hline Molybdenum, mg/kg & - & 1.5 & - & - & - & - \\
\hline Zinc, mg/kg & 45 & 57.8 & - & 71 & - & 55 \\
\hline Selenium, mg/kg & - & 1.22 & - & 1.00 & - & 0.1 \\
\hline
\end{tabular}

Canola meal has a reasonable amount of amino acid (Table 5) containing high amount of sulfur amino acid, $[43,44]$ while comparatively lower in lysine and argininecontent than soybean meal [17]. Prepress solvent extracted canola meal is characterized with lower and less consistent amino acid digestibility in broilers than soybean meal $[43,40]$. Some amino acids, especially lysine can be turned to biologically unavailable lysine derivatives (un-reactive lysine) during heat processing as well as prolonged storage of feedstuffs $[45,46]$.

Table 4 Vitamin content of the canola meal and soybean meal (As fed basis)

\begin{tabular}{|c|c|c|c|c|c|c|c|}
\hline \multirow[t]{2}{*}{ Vitamins (mg/kg) } & \multicolumn{4}{|c|}{ Canola meal } & \multicolumn{3}{|c|}{ Soybean meal } \\
\hline & [37] & {$[6]$} & [23] & [41] & [40] & [16] & [42] \\
\hline $\begin{array}{l}\text { Vitamin E } \\
\text { (alpha tocopherol) }^{\mathrm{a}}\end{array}$ & 20.89 & 21.64 & 13 & - & 4.47 & 3.58 & 3.43 \\
\hline Pantothenic acid & 9.5 & 9.5 & 9.3 & 9.5 & 15 & 16.3 & 15 \\
\hline Niacin & 160 & 160 & 156 & 160 & 22 & 28 & 22 \\
\hline Choline & 6700 & 6700 & 6500 & 6700 & 2700 & 2609 & 2730 \\
\hline Riboflavin & 5.8 & 5.8 & 5.7 & 5.8 & 2.9 & 2.9 & 3.1 \\
\hline Biotin & 1.1 & 1.07 & 0.96 & 0.98 & 0.32 & 0.32 & 0.26 \\
\hline Folic acid & 2.3 & 2.3 & 0.8 & 0.83 & 1.3 & 0.6 & 1.37 \\
\hline Pyridoxine & 7.2 & 7.2 & 7.0 & - & 5.0 & 6.0 & - \\
\hline Thiamin & 5.2 & 5.2 & 5.1 & 5.2 & 3.2 & 6.0 & 3.2 \\
\hline
\end{tabular}

Dashes indicate that no data were available anits in IU/Kg 
Table 5 Amino acid content (As fed basis)

\begin{tabular}{|c|c|c|c|c|c|c|c|c|c|}
\hline \multirow[t]{2}{*}{ Amino acid (g/kg) } & \multicolumn{3}{|c|}{ Expeller extracted canola meal } & \multicolumn{4}{|c|}{ Solvent extracted canola meal } & \multicolumn{2}{|c|}{ Soybean meal } \\
\hline & [24] & [26] & [5] & [24] & [27] & {$[28]^{a}$} & {$[5]$} & [47] & [25] \\
\hline Methionine & 7.0 & 7.1 & 7.0 & 7.2 & 7.1 & 8.6 & 7.2 & 6.6 & 6.3 \\
\hline Cystine & 8.6 & - & 8.5 & 8.7 & - & 12.0 & 8.6 & 6.6 & 7.3 \\
\hline Methionine + Cystine & 15.6 & - & 15.6 & 16.0 & - & - & 15.9 & - & 13.6 \\
\hline Lysine & 19.7 & 19.8 & 19.6 & 20.2 & 20.2 & 24.9 & 20.0 & 30.4 & 28.9 \\
\hline Threonine & 15.0 & 15.1 & 15.0 & 15.6 & 15.6 & 19.0 & 15.7 & 18.2 & 18.4 \\
\hline Tryptophan & 4.9 & 4.4 & 4.8 & 5.1 & 3.9 & 5.3 & 5.0 & 6.8 & 6.3 \\
\hline Arginine & 21.5 & 21.5 & 21.0 & 22.1 & 21.8 & 26.0 & 21.8 & 35.6 & 34.8 \\
\hline Isoleucine & 13.9 & 15.0 & 13.9 & 14.3 & 13.9 & 17.8 & 14.3 & 22.4 & 21.7 \\
\hline Leucine & 24.3 & 25.2 & 24.3 & 25.3 & 25.5 & 30.4 & 25.4 & 37.6 & 36.0 \\
\hline Valine & 17.9 & 18.8 & 17.9 & 18.6 & 18.0 & 22.9 & 18.6 & 23.6 & 23.0 \\
\hline Histidine & 9.5 & 9.6 & 9.5 & 9.9 & 9.6 & 15.4 & 9.8 & 12.5 & 12.1 \\
\hline Phenylalanine & 14.1 & 14.3 & 13.9 & 14.6 & 14.6 & 17.1 & 14.6 & 24.3 & 23.7 \\
\hline
\end{tabular}

Dashes indicate that no data were available

${ }^{a}$ Ether extracted dry matter basis

The fatty acid profile is different between expeller and solvent extracted meal. Palmitic acid and linoleic acid were consistently higher in solvent extracted meal but oleic and linolenic acids were lower than expeller meal [24]. This remarks mechanical extraction leads to superior removal of oleic and linolenic acids from the seed [24].

\section{Anti-nutritional factors in canola meal}

Canola meal cannot be substantial as full protein supplement in poultry diet, due to the inherent anti-nutritional factors (ANF) (Table 6). These ANF hinder animal growth performance by interfering with nutrient absorption in the digestive system [44]. Phenolics are one of the ANF which is unwanted and undesirable in animal feed. Among all phenolics, sinapine is the most abundant phenolic in canola that caused 'fishy' or 'crabby' tainted eggs in hens [44]. However, off flavor has not been detected in broiler carcasses due to the sinapine [17]. To eliminate sinapine from meal, plant breeding is economically better than physical process [48]. Another ANF found in canola meal is phytate, a complex of inositol and phosphorus [49]. Phytate is not bioavailable as a phosphorus source to non-ruminant animals and fish due to lack of enzyme degrading phytate phosphorus [44]. Feeding phytate in non-ruminant animals can lead to a hypertrophy of the thyroid glands, and subsequently to lower growth performance [50-52]. Hydrolyzing phytic acid by enzymatic methods (exogenous phytase) was studied previously $[53,54]$, and they found that about $72-73 \%$ of meal phytate could be hydrolyzed by addition of phytase [54] and improved feed to gain ratio. Whilst, no significant growth performance was observed [54]. It can be applied to canola meal to overcome above mentioned potential problems. Canola meal contains considerable amounts of glucosinolates that can break down into various compounds (i.e., thiocyanate, isothiocyanate, oxazolidinethione and nitriles) which are known to have a negative effect upon animal growth performance. Level of glucosinolates found in canola seed ranges from 3.6 to $9.2 \mu \mathrm{mol} / \mathrm{g}$ [24] and this content should restrict to $1-1.5 \mu \mathrm{mol} / \mathrm{g}$ feed and to even lower concentrations for young monogastric animals [55]. However, this level can be up to $4 \mu \mathrm{mol} / \mathrm{g}$ for layers and $1.5 \mu \mathrm{mol} / \mathrm{g}$ was recommended for broilers [17].

High fiber content of canola meal is one of the critical factors limiting the increased use of canola meal in poultry diets [56-59]. Dietary fiber contents account for approximately one-third of the meal, and consist of cellulose (4-6\%), non-cellulosic polysaccharides (13$16 \%)$, lignin and polyphenols (5-8 \%), and protein and minerals associated with the fiber fraction [35]. Large amounts of crude fiber are present in the hulls of oil seeds, which contain carbohydrate fraction and proteins along with non-starch polysaccharides (NSP) [60]. Dehulling is one of the methods to reduce negative effects of the fiber. It has been documented that dehulling improved digestibility (for amino acid), amino acid and energy utilization of canola meal when fed to broiler chicken [61]. However, dehulling increases the unit cost of production in the commercial scale [62]. The simple way to overcome this problem is through genetic selection and plant breeding to make the seed coat thinner. This provides alternative way to improve the canola meal quality. It may be possible to breed a new variety of canola with thin seed coat, lower fiber and more protein contents [63, 64]. A recent study revealed superior quality characters in canola meal derived from the newly developed low fiber fraction line 
Table 6 Amount of anti-nutritional factors in canola meal and their main effects

\begin{tabular}{|c|c|c|c|c|}
\hline \multicolumn{4}{|l|}{ Component } & \multirow[t]{2}{*}{ References } \\
\hline Sinapine \% & Phytic acid \% & Glucosinolates $\left(\mu \mathrm{mol} \mathrm{g}{ }^{-1}\right)$ & Tannins, \% & \\
\hline \multicolumn{5}{|l|}{ Average amount } \\
\hline $0.6-1.8$ & $3.0-6.0$ & 18.3 & $1.5-3.0$ & {$[37]$} \\
\hline $0.6-1.8$ & $3.0-6.0$ & $10-12$ & $1.5-3.0$ & {$[6]$} \\
\hline 1.0 & 4.0 & 16 & 1.5 & [25] \\
\hline 1.0 & - & 5.5 & - & {$[17]$} \\
\hline $0.79-0.97$ & - & $1.73-5.26$ & - & {$[5]$} \\
\hline \multicolumn{5}{|l|}{ Effects on poultry } \\
\hline Bitter flavor. & \multirow[t]{2}{*}{ Binds minerals } & \multirow{2}{*}{$\begin{array}{l}\text { Enlargement of internal organs like } \\
\text { liver and Kidney }\end{array}$} & \multirow{2}{*}{$\begin{array}{l}\text { Impairs digestion. Especially } \\
\text { protein }\end{array}$} & \multirow[t]{2}{*}[6]{} \\
\hline Layers produce "Fishy eggs". & & & & \\
\hline Production of off flavor "Fishy eggs" & \multirow{2}{*}{$\begin{array}{l}\text { Render the minerals and } \\
\text { make them unavailable } \\
\text { for absorption }\end{array}$} & \multirow{2}{*}{$\begin{array}{l}\text { Decrease the growth rates of broilers, } \\
\text { increase the thyroids and liver sizes } \\
\text { and cause hemorrhagic liver syndrome }\end{array}$} & \multirow{2}{*}{$\begin{array}{l}\text { Interfere with digestive } \\
\text { enzymes and lower the } \\
\text { nutrient utilization }\end{array}$} & \multirow[t]{2}{*}[37]{} \\
\hline By layer hens & & & & \\
\hline- & - & $\begin{array}{l}\text { No real evidence that canola cultivars } \\
\text { with zero glucosinolates may cause } \\
\text { any effect }\end{array}$ & - & {$[25]$} \\
\hline "Fishy taint" in brown shell egg & $\begin{array}{l}\text { Make protein and minerals } \\
\text { biologically unavailable. }\end{array}$ & $\begin{array}{l}\text { Interfere with the function of thyroid } \\
\text { gland and adversely affect growth } \\
\text { performance }\end{array}$ & $\begin{array}{l}\text { Affect protein digestion and } \\
\text { poor growth performance } \\
\text { in broiler }\end{array}$ & {$[17]$} \\
\hline
\end{tabular}

Dashes indicate that no data were available

of yellow-seeded B. napus with having more protein, more sucrose, and less dietary fiber contrasting to black-seeded B. juncea [22].

\section{Energy content}

The energy content of canola meal was evaluated for poultry last for 20 years (Table 7). The amount of energy supply from canola meal is directly related to the residual oil in the meal. However, canola meal consists with comparatively lower metabolizable energy (ME) level than other protein sources such as soybean meal in poultry diet $[43,40]$. This is because of the higher fiber content of the canola meal that dilutes the energy content [61]. The ME content of expeller-pressed canola meal is higher than that of solvent-extracted canola meal

Table 7 Available energy value for canola meal $(\mathrm{kcal} / \mathrm{kg})^{\mathrm{a}}$

\begin{tabular}{llll}
\hline AMEn & TME & TMEn & Reference \\
\hline 1980 & - & 2090 & {$[13]^{\mathrm{b}}$} \\
2000 & - & 2070 & {$[23,40]^{\mathrm{c}}$} \\
2390 & - & - & {$[23]^{\mathrm{c}}$} \\
2186 & 2764 & 2439 & {$[14]^{\mathrm{d}}$} \\
- & 2049 & 1964 & {$[66]^{\mathrm{b}}$} \\
2390 & - & - & {$[67]^{\mathrm{e}}$} \\
1910 & - & - & {$[67]^{\mathrm{c}}$} \\
\hline
\end{tabular}

Dashes indicate that no data were available

${ }^{a}$ Abbreviations are AMEn Apparent metabolizable energy, N-corrected, TME

True metabolizable energy and TMEn True metabolizable energy, N-corrected

Animal used : ${ }^{b}$ White Leghorn roosters, ${ }^{c}$ Broilers, ${ }^{d}$ White Pekin ducks,

'Layer hen due to higher residual oil [65]. Metabolizable energy values of the meal have improved via plant breeding by reducing glucosinolate levels [6]. Dehulling of canola meal resulted in improved ME levels along with digestible energy value. Canola meal contains about 3,346 kcal/kg digestible energy while dehulled canola meal contains approximately 4,063 kcal/ $\mathrm{kg}$ digestible energy, due to reduction of fiber component in hulls which comprise about $12-16 \%$ of canola seeds [6]. Other factors that may influence the ME content of meal include its content of fiber, protein and oil. These factors are influenced by variety and seed quality along with feed processing technology [6]. Additivity and associative effects of metabolizable energy in canola meal was studied for white Pekin ducks [14]. It was reported 2,186 kcal/kg AMEn and 2,439 kcal/ $\mathrm{kg}$ TMEn values for canola meal, which are higher $(2,000$ and 2,070 $\mathrm{kcal} / \mathrm{kg}$, respectively) than NRC (1994) values. Moreover, those energy values are higher in ducks than chickens [14].

\section{Amino acid for ducks}

With regard to the amino acid requirement of ducks, greatest attention should be given to the sulfur amino acids (i.e., methionine and cysteine) because they are generally considered to be the first limiting amino acids for ducks [42] similar to other poultry [68]. Requirement of total sulfur amino acids for male Muscovy ducklings was $0.60 \%$ (diet contain, $988 \mathrm{kcal} / \mathrm{kg} \mathrm{ME}$ ) and $0.55 \%$ (diet contain $3,090 \mathrm{kcal} / \mathrm{kg} \mathrm{ME}$ ) to achieve maximal growth from 3 to 6 and 6 to 10 weeks, respectively [69]. 
Based on straight-run Mule ducklings, it was concluded that $0.59 \%$ total sulfur amino acids were required (diet contain $2,892 \mathrm{kcal} / \mathrm{kg} \mathrm{ME}$ ) for maximal growth and feed efficiency [70].

Canola has a reasonably well balanced amino acid profile for ducks. Although it is deficient in lysine content, it is rich in sulfur amino acids [17]. A recent study confirmed methionine and cysteine contents were higher in canola meal (0.91\%: $1.21 \%)$ than soybean meal (0.69 \%:0.68 \%) [71]. Accordingly, utilization of canola meal has potential to meet sulfur amino acid requirement for duck as an alternative feed ingredient to soybean meal. Amino acid digestibility of canola meal in duck is presented in Table 8. Lower amino acids digestibility of canola meal than those in soy bean meal except for cysteine was observed in the study with white Pekin ducks [47]. However, this low amino acid digestibility results from higher levels of hulls and tannins in canola compared soybean meal [72]. Nutritional value of canola meals from new varieties of canola when compared to conventional canola meal samples and soybean meals fed to chickens were evaluated [71]. In this study, genetically selected new varieties had more amino acids content and amino acid digestibility with compared to conventional canola meal. It has been concluded that same amino acid digestibility values could be used for

Table 8 Digestibility coefficients of amino acids for duck (3 weeks old white Pekin ducks)

\begin{tabular}{llcc}
\hline Amino acid & \multicolumn{3}{l}{ Apparent ileal digestibility (\%) } \\
\cline { 2 - 4 } & {$[23]$} & {$[47]$} & {$[74]$} \\
\hline Alanine & 66.0 & 79.2 & 79.3 \\
Arginine & 71.0 & 87.1 & 87.1 \\
Aspartate + asparagine & 60.0 & 74.6 & 74.6 \\
Cystine & 67.0 & 70.9 & 70.9 \\
Glutamate + glutamine & 81.0 & 85.9 & 85.9 \\
Glycine & 59.0 & 74.5 & 74.5 \\
Histidine & - & 82.7 & 82.7 \\
Isoleucine & 65.0 & 77.7 & 77.7 \\
Leucine & 73.0 & 79.4 & 79.4 \\
Lysine & 66.0 & 79.0 & 79.0 \\
Methionine & 80.0 & 84.8 & 84.7 \\
Phenylalanine & 73.0 & 81.5 & 81.5 \\
Proline & - & 75.7 & 75.7 \\
Serine & 70.0 & 71.4 & 71.4 \\
Threonine & 64.0 & 69.6 & 69.6 \\
Tryptophan & - & 84.9 & 84.9 \\
Tyrosine & - & 76.4 & 76.4 \\
Valine & 62.0 & 74.1 & 74.1 \\
\hline Dashes & & &
\end{tabular}

Dashes indicate that no data were available ducklings and chicks based on the digestibility studies done with domestic chicks and Muscovy ducks [73].

\section{Minerals for ducks}

The most important minerals for ducks are calcium $(\mathrm{Ca})$ and phosphorus (P). These are needed for bone formation, egg shell formation and maintenance of ducks. Ducklings' requirement of Ca:P ratio is between 1:1 and $2: 1$. For laying ducks, this ratio is $6: 1$ and they need $4.0 \mathrm{~g}$ of calcium every day for egg shell formation [75]. Furthermore, dietary available phosphorus (AP) levels influenced the mean egg weight and $4.0 \%$ calcium with $0.6 \% \mathrm{AP}$ was optimum for indigenous layer ducks [76]. It was reported that maximum weight and feed conversion were obtained for White Pekin ducklings when fed practical type rations containing $0.7-0.9 \%$ total phosphorus [77]. Canola meal is enriched with AP $(0.38 \%)$ with compared to other vegetable sources like soybean meal $(0.28 \%)$ and wheat $(0.09 \%)$ [17].

Information on the mineral value of canola meal in duck diets is not accessible. There was no significant effect of replacing soybean meal with canola meal in broiler diet (21 days old broilers) on apparent retention and bone content of calcium and phosphorus [78]. In the same study, no effect of replacing soybean meal with canola meal was observed in laying hen with respect to apparent retention and bone content of calcium and phosphorus [78].

\section{Feeding value of canola meal for duck}

Canola meal is used as alternative protein source in all types of poultry feeds. Last three decades, many studies focused on canola meal utilization on chickens and swine as these are leading livestock industries. Therefore, limited information is available for its utilization for ducks. Canola meal is commonly fed to ducks and geese without any problems [23]. Geese have a greater digestive capability than other types of poultry and hence, it appears to digest canola meal more efficiently than other poultry [79]. It is estimated that up to $15 \%$ of canola meal can be included in a diet for duck without compromising production indices [23, 44]. For broilers (first 5 weeks of age), supplementation of canola meal at the level of $25 \%$ showed maximum weight and improved feed conversion ratio [80]. Conventional canola meal (rapeseed meal with high glucosinolates) showed negative effect on the growth performance of Mule ducks at the starting period [52]. Even though glucosinolates have affected the thyroid functioning and probably the thyroxin production, duck appeared less sensitive and did not adversely affect the meat production during the growing period, and thereby it is possible to use higher incorporation rate in the latter period. Moreover, as canola meal 
contains low amount of glucosinolates than rapeseed meal aforementioned problems may not exist with canola meal.

Low glucosinolate canola meal (BC 86-16) showed high rate of egg production when supplemented $24-25 \%$ of the diet [81]. Similarly, it was observed no effects on egg production, egg weight and body weights of the layers when soybean meal was partially replaced with canola meal [82].

No adverse sensory effects were observed with canola meal containing diets up to $210 \mathrm{~g} / \mathrm{kg}$ in the starter with $90 \mathrm{~g} / \mathrm{kg}$ in the finisher on meat quality of broiler chickens [83]. Furthermore, carcass yields of broiler chickens were not different in broiler chickens fed diets containing either soybean meal or 10 or $20 \%$ full fat canola [84]. In this regard, inclusion of canola meal in duck diets may not affect in meat quality. Nevertheless, canola seed hulls tend to stick in the digestive track of poultry which may lower the carcass quality during processing [23].

\section{Canola meal enhancement on duck}

Canola meal component which impacts on duck health should be considered when feeding. Basically, ANFs play a major role in duck health. As mentioned before in previous section fiber portion of canola meal considered as an ANF. However, cell wall polysaccharides can be converted to the substances that are stimulating healthy microbial growth in the gastrointestinal tract using commercially available in-feed enzymes [85]. Galacto-, gluco-, manno-, or xylo-oligomers can be produced by supplementing non-starch polysaccharide hydrolyzing enzymes in a diet containing canola meal [86], lending prebiotic effect. Prebiotics may selectively encourage favorable microbial population and thereby reduce incidence of enteric pathogens in the intestinal system [87]. When canola meal is treated with carbohydrase enzymes it can reduce substrate availability for harmful microbial growth in the ileum and improve nutrient digestion and absorption [88, 89]. Similarly, multi-carbohydrase enzyme acts on the NSP in canola meal, resulted in reduced amounts of water insoluble NSP and increased amounts of water soluble NSP, and increased NSP hydrolysis products with some monosaccharides. Galactose, glucose and uronic acid were predominant among the released monosaccharides [90]. Similarly, it was documented that correct blend of carbohydrase enzymes acting on NSP could produce lowmolecular weight polysaccharides, simple sugars and oligosaccharides, which improve gut environment by being utilized as prebiotics for beneficial microbes in the intestinal tract [91]. Moreover, exogenous enzymes improve digestibility and growth performance of the birds by means of improving gut morphology [92].

\section{Conclusion}

As an alternative feed ingredient, canola is the possible alternative vegetable protein source which can substitute soybean meal. It consists of well-balanced amino acid profile and rich in methionine and cysteine. It also riches in vitamins with compared to other vegetable protein sources. Carcass yield and sensory quality were not affected by feeding canola meal. Downgrading factors like fiber content and phytic acid can be eliminate by using hydrolyzing enzymes. With these enzymes, feeding value of canola meal can be enhanced with potential health benefits in birds. Collectively, it is expected that canola meal shows a great potential for duck nutrition as an alternative feed ingredient. However, more researches are needed to confirm duck performance with canola meal in future.

\section{Competing interests}

The authors declare that they have no competing interests.

\section{Authors' contributions}

Wrote the manuscript: SSW YJY JY. Read and commented and suggested on the earlier drafts of the manuscript: KNK JMH. All authors read and approved the final manuscript.

\section{Acknowledgements}

This paper was financially supported by the research fund of National Institute of Animal Science (PJ 01011403).

\section{Author details}

${ }^{1}$ Division of Animal and Dairy Science, Chungnam National University, Daejeon 305-764, Republic of Korea. ${ }^{2}$ Division of Biotechnology, College of Environmental \& Bioresources, Chonbuk National University, Iksan-si, Jeollabuk-do 570-752, Republic of Korea.

Received: 11 June 2015 Accepted: 7 August 2015

Published online: 01 September 2015

\section{References}

1. Swick RA. Considerations in using protein meal for poultry and swine. ASA technical Bulletin Vol. AN 21.1999. http://www.asaimsea.com/pdfs/AN21-swick.pdf. Accessed 16 July 2014.

2. Laudadio V, Tufarelli V. Growth performance and carcass and meat quality of broiler chickens fed diets containing micronized-dehulled peas (Pisum sativum cv.Spirale) as a substitute of soybean meal. Poult Sci. 2010;89:1537-43.

3. Xu FZ, Li LM, Xu JP, Qian K, Zhang ZD, Liang ZY. Effects of fermented rapeseed meal on growth performance and serum parameters in ducks. Asian-Aust J Anim Sci. 2011;24:678-84.

4. Newkirk RW. Canola meal feed industry guide. 4th ed. Winnipeg: Canola Council of Canada; 2009. http://www.canolacouncil.org/media/516716/ canola_meal_feed_guide_english.pdfv. Accessed 16 July 2014.

5. Spragg JC, Mailer RJ. Canola meal value chain quality improvement. A final report for AOF and Pork CRC. 2008. http://www.australianoilseeds.com/_data/ assets/pdf_file/0011/5798/AOF_Stage_2_Protein_Meal_Report.pdf. Accessed 15 July 2014.

6. Bell JM. Factors affecting the nutritional value of canola meal: a review. Can J Anim Sci. 1993;73:679-97.

7. CCC. Canadian canola meal. Winnipeg: Canola Council of Canada; 1990.

8. CCC. Canola meal feed industry guide. Winnipeg: Canola Council of Canada; 1997.

9. Slominski BA, Jia W, Rogiewicz A, Nyachoti CM, Hickling D. Low-fiber canola: chemical and nutritive composition of the meal. J Agric Food Chem. 2012;60:12225-30.

10. Clandinin DR. Canola meal for livestock and poultry. Winnipeg: Canola Council of Canada; 1989.

11. Sibbald IR. A bioassay for true metabolizable energy in feedstuffs. Poult Sci. 1976;55:303-8.

12. Clandinin DR, Robblee AR. Apparent and true metabolizable energy values for low glucosinolate-type rapeseed meal. Feedstuffs. 1983;55:5-20. 
13. Lee KH, Qi GE, Sim JS. Metabolizable energy and amino acid availability of full-fat seeds, meals, and oils of flax and canola. Poult Sci. 1995;74:1341-8.

14. Hong D, Ragland D, Adeola O. Additivity and associative effects of metabolizable energy and amino acid digestibility in barley and canola meal for White Pekin ducks. Poult Sci. 2001;80:1600-6.

15. Kong C, Adeola O. Comparative amino acid digestibility for broiler chickens and White Pekin ducks. Poult Sci. 2013;92(9):2367-74.

16. Tiwari SP, Kumari K, Gendley MK. Use of Azolla (Azolla Pinnata) as a protein supplement in the diet of semi - scavenging Khaki Cambell layer ducks. 2009; 200 In: Proceeding of fourth World Waterfowl Conference. http:// www.waterfowl2009.vetcos.com/proceedings\%20-\%20IV\%20WWC\%20\%20Kerala,\%20India.pdf Accessed 15 July 2015.

17. Khajali F, Slominski BA. Factors that affect the nutritive value of canola meal for poultry. A review. Poult Sci. 2012;91:2564-75.

18. Ali MS, Kang GH, Yang HS, Jeong JY, Hwang $Y H$, et al. A comparison of meat characteristics between duck and chicken breast. Asian Australas J Anim. 2007;20:1002-6.

19. Scanes CG. Editorial: the global importance of poultry. Poult Sci. 2007:86:1057-8.

20. Adzitey F, Adzitey SP. Duck production: has a potential to reduce poverty among rural households in Asian communities - a review. J World's Poult Res. 2011:1:7-10.

21. Tai C, Tai JJL. Future Prospects of duck production in Asia. J Poult Sci. 2001;38(1):99-112.

22. Jia W, Mikulski D, Rogiewicz A, Zdunczyk Z, Jankowski J, Slominski BA. Low-fiber Canola (2) nutritive value of the meal. J Agric Food Chem. 2012;60:12231-7

23. CCC. Canola meal feed industry guide, 4th ed. Canola Council of Canada, Winnipeg, Manitoba, Canada; 2009.

24. Spragg JC, Mailer RJ. Canola meal value chain quality improvement. A final report for AOF and Pork CRC. 2007. http://www.porkcrc.com.au/ Final_Report_1B-103.pdf. Accessed 16 June 2014.

25. Mailer R. Canola meal, limitation and opportunities. Australian Oilseed Federation. 2004. http://www.australianoilseeds.com/__data/assets/pdf_file/0011/1271/ AOF_Canola_Meal_Report-Limitations_and_Opportunities_2004.pdf. Accessed 10 July 2015.

26. Landero JL, Beltranena E, Cervantes M, Araiza AB, Zijlstra RT. The effect of feeding expeller-pressed canola meal on growth performance and diet nutrient digestibility in weaned pigs. Anim Feed Sci Technol. 2012;171:240-5.

27. Landero JL, Beltranena E, Cervantes M, Morales A, Zijlstra RT. The effect of feeding solvent-extracted canola meal on growth performance and diet nutrient digestibility in weaned pigs. Anim Feed Sci Technol. 2011;170:136-40.

28. Bell JM, Keith MO. A survey of variation in the chemical composition of commercial canola meal produced in Western Canadian crushing plants. Can J Anim Sci. 1991;71:469-80.

29. Spragg JC. Canola meal NIR calibration implementation: A report for AOF and Pork CRC. 2013. http://porkcrc.com.au/wp-content/uploads/2014/01/4B118-Final-Report-.pdf. Accessed 10 July 2014.

30. Seneviratne RW, Young MG, Beltranena E, Goonewardene LA, Newkirk RW, Zijlstra RT. The nutritional value of expeller-pressed canola meal for growerfinisher pigs. J Anim Sci. 2010;88:2073-83.

31. Moughan PJ, Rutherfurd SM. A new method for determining digestible reactive lysine in foods. J Agric Food Chem. 1996;44:2202-9.

32. Newkirk RW, Classen HL. The effects of toasting canola meal on body weight, feed conversion efficiency, and mortality in broiler chickens. Poult Sci. 2002:85:815-25.

33. van Barneveld RJ, Batterham ES, Norton BW. The effect of heat on amino acids for growing pigs. 2. Utilization of ileal-digestible lysine from heat-treated field peas (Pisum sativum cultivar Dundale). Br J Nutr. 1994;72:243-56.

34. Barac M, Stanojevic S. The effect of microwave roasting on soybean protein composition and components with trypsin inhibitor activity. Acta Aliment. 2005;34:23-31.

35. Slominski BA, Campbell LD. Non-starch polysaccharides of canola meal: quantification, digestibility in poultry and potential benefit of dietary enzyme supplementation. J Sci Food Agric. 1990;53:175-84.

36. Johnsson R, Bengtsson L. Yellow seeded rape and turnip rape - Influence of breeding for yellow seeds upon yield and quality properties. Sver Utsaedesfoeren Tidskr. 1970;2(3):149-55.

37. Liang D. Effect of enzyme supplementation on the nutritive value of canola meal for broiler chickens. Msc. dissertation, Faculty of graduate studies, University of Manitoba.2000. http://www.collectionscanada.gc.ca/obj/s4/f2/ dsk1/tape2/PQDD_0012/MQ53178.pdf. Accessed 21 May 2014.
38. Summers JD, Bedford M, Spratt D. Amino acid supplementation of canola meal. Can J Anim Sci. 1989;69:469-75.

39. Sariçiçek BZ, Kiliç Ü, Garipoglu AV. Replacing soybean meal (SBM) by canola meal (CM): the effects of multi-enzyme and phytase supplementation on the performance of growing and laying quails. Asian-Aust J Anim Sci. 2005;18:1457-63.

40. National Research Council. Nutrient requirements of poultry. 9th ed. Washington, DC: National Academy Press; 1994.

41. Maison T. Evaluation of the nutritional value of canola meal, 00-rapeseed meal, and 00-rapeseed expellers fed to pigs. (Doctoral dissertation) Department of Animal Science, University of Illinois at Urbana-Champaign. 2013. https://www.ideals.illinois.edu/bitstream/handle/2142/46593/ Tanawong_Maison.pdf?sequence=1. Accessed 10 July 2015.

42. Choo YK, Kwon HJ, Oh ST, et?al. Growth performance and carcass characteristics of Korean native ducks fed diets with varying levels of limiting amino acids. Asian-Aust J Anim Sci. 2014;27(4):518-23.

43. Newkirk RW, Classen HL, Edney MJ. Effect of prepress-solvent extraction on the nutritional value of canola meal for broiler chickens. Anim Feed Sci Technol. 2003;1047:111-9.

44. Bonnardeaux J. Uses for canola meal. Department of agriculture and food, Western Australia.2007. http://www.agric.wa.gov.au/objtwr/imported assets/ content/sust/biofuel/usesforcanolameal_report.pdf. Accessed Jan. 9, 2011.

45. Kim JC, Mullan BP, Pluske JR. Prediction of apparent, standardized, and true ileal digestible total and reactive lysine contents in heat-damaged soybean meal samples. J Anim Sci. 2012;90 Suppl 4:137-9.

46. Kim JC, Mullan BP. Quantification of the variability in the amino acid and reactive Iysine content of soybean meal and development of A NIR calibration for rapid prediction of reactive lysine content. South Perth, WA 6151: Livestock Industries Innovation, Department of Agriculture and Food 3 Baron-Hay Court; 2012.

47. Kong C, Adeola O. Apparent ileal digestibility of amino acids in feedstuffs for White Pekin ducks. Poult Sci. 2010;89:545-50.

48. McFadden A, Mailer RJ. Sinapine in Australian Canola. Tamworth: In: 13th Biennial Australian Research Assembly on Brassicas; 2003. p. 96-8.

49. Ravindran $V$, Bryden WL. Influence of phytic acid and available phosphorus levels on the response of broilers to supplemental Natuphos. Poult Res Foundation Rep, University of Sidney, Australia. 1997.

50. Sturkie PD. Avian physiology. 4th ed. Springer-Verlag New York. 1986. p. 452-65.

51. Tadelle D, Alemu Y, Moges HM, Fasil K. Effect of level of rapessed cake in rations on broiler performance. Livest Res Rural Dev. 2003;15:4.

52. Bernadet MD, Peillod C, Lessire M, Guy G. Incorporation of Rapeseed meal in mule duck diets. Proceedings of IV world waterfowl conference, Thrissur, India. 2009; 161

53. Al-Asheh S, Duvnjak Z. The effect of surfactants on the phytase production and the reduction of the phytic acid content in canola meal by Aspergillus carbonarius during a solid state fermentation process. J Biotechnol Lett. 1994;16(2):183-8.

54. Newkirk RW, Classen HL. The non-mineral nutritional impact of phytate in canola meal fed to broiler chicks. Anim Feed Sci Technol. 2001;91(3):115-28.

55. European Food Safety Authority. Glucosinolates as undesirable substances in animal feed. The EFSA J. 2008;590:1-76.

56. Grala WL, Buraczewska J, Gdala, Pastuszewska B. Effect of toasting temperature on protein value of rapeseed oil meal for pigs. J Anim Feed Sci. 1994;3:33-42.

57. Pastuszewska B, Jablecki G, Buraczewska L, Dakowski P, Taciak M, Matyjek R, et?al. The protein value of differently processed rapeseed solvent meal and cake assessed by in?vitro methods and in tests with rats. Anim Feed Sci Technol. 2003;106:175-88.

58. Thacker PA, Newkirk RW. Performance of growing finishing pigs fed barleybased diets containing toasted or non-toasted canola meal. Can J Anim Sci. 2005;85:53-9.

59. Montoya CA, Leterme P. Determination of the digestible energy and prediction of the net energy content of toasted and non-toasted canola meals from Brassica juncea and Brassica napus in growing pigs by the total faecal collection and the indigestible marker methods. Can J Anim Sci. 2009;89:481-7.

60. Naczk M, Amarowicz R, Sullivan BA, Shahidi F. Current research developments on polyphenolics of rapeseed/canola: a review. J Food Chem. 1998;62(4):489-502.

61. Clark WD, Classen HL, Newkirk RW. Assessment of tail-end dehulled canola meal for use in broiler diets. Can J Anim Sci. 2001;81:379-86. 
62. Shires A, Bell JM, Laverty WH, Fedec P, Blake JA, McCregor DI. Effect of desolventization conditions and removal of fibrous material by screening on the nutritional value of canola rapeseed meal for broiler chickens. Poult Sci. 1983:62:2234-44

63. Newkirk RW, Classen HL, Tyler RT. Nutritional evaluation of low glucosinolate mustard meal (Brassica jtmcea) in broiler diets. Poult Sci. 1997;76:1272-7.

64. Slominski BA. Developments in the breeding of low fiber rapeseed/canola. J Anim Feed Sci. 1997:6:303-17.

65. Smulikowska S, Pastuszewska B, Mieczkowska A, Ochtabinska A. Chemical composition, energy value for chickens, and protein utilization in rats of rapeseed expeller cakes produced by different pressing technologies. J Anim Feed Sci. 1997;6:109-21.

66. Barbour GW, Sim JS. True metabolizable energy and true amino acids availability in canola and flax products for poultry. Poult Sci. 1991;70:2154-60.

67. Perez-Maldonado RA. Canola meal and cottonseed meal in broiler and layer diets. A report for the Australian Egg Corporation Limited. AECL Publication No. 03/10 (2003). https://www.aecl.org/assets/RD-files/Outputs-2/DAQ264JA-Final-Report.pdf. Accessed 12 July 2015.

68. Scott ML, Nesheim MC, Young RJ. Nutrition of the chicken. 3rd ed. M.L. Scott and Associates, Ithaca, NY. 1982;99-100.

69. Leclerca B, de Carville $\mathrm{H}$. On the sulphur amino acid requirement of Muscovy ducklings. Archiv fur Geflugelkunde. 1977;41:270-2.

70. Hsieh HH, Shen TF. Sulfur amino acid requirements of mule duckling. J Chinese Anim Sci. 1980;9:7-15.

71. Chen XC, Parr P, Utterback, Parsons CM. Nutritional evaluation of canola meals produced from new varieties of canola seeds for poultry. Poult Sci. 2015;00:1-8

72. Ravindran V, Hew LI, Ravindran G, Bryden WL. Apparent ileal digestibility of amino acids in dietary ingredients for broiler chickens. Anim Sci. 2005;81:85-97.

73. Mohamed K, Larbier M, Leclercq B. A comparative study of the digestibility of soya bean and cottonseed meal amino acids in domestic chicks and Muscovy ducklings. Ann Zootech. 1986;35:79-85.

74. Adeola L. Midwest Poultry Research Program lleal Digestibility of Amino Acids in Feeds for White Pekin Ducks. http://www.mwpoultry.org/ ProjectPDFs/07-16.pdf. Accessed 12 July 2015.

75. Van der Meulen SJ, Dikken GD. Duck Keeping in the Tropics. Wageningen, Agromisa Foundation. 2004. http://journeytoforever.org/farm_library/ AD33.pdf. Accessed 22 June 2014

76. Ravi S, Peethambaran PA, Jalaludeen A, Leo J, Gangadevi P. Influence of dietary calcium and phosphorus levels on production performance in indigenous layer ducks in cages. Proceeding of fourth World Waterfowl Conference. 2009; 170-174. http://www.waterfowl2009.vetcos.com/proceedings\%20\%20IV\%20WWC\%20-\%20Kerala,\%20India.pdf. Accessed 15 Aug 2014

77. Dean WF, Scott ML, Young RJ, Ash WJ. Calcium requirement of ducklings. Poult Sci. 1967;46:1496-9.

78. Leeson S, Atteh JO, Summers JD. The replacement value of canola meal for soybean meal in poultry diets. Can J Anim Sci. 1987;67:151-8.

79. Jamroz DA, Wiliczkiewicz, Skorupinska J. The effect of diets containing different levels of structural substances on morphological changes in the intestinal walls and the digestibility of the crude fiber fractions in geese. J Anim Feed Sci. 1992;1(3):37-50.

80. Naseem MZ, Khan SH, Yousaf M. Effect of feeding various levels of canola meal on the performance of broiler chicks. J Anim PI Sci. 2006;16:3-4.

81. Campbell LD, Slominski BA. Nutritive quality of low-glucosinolate meal for laying hens. Proc 8th Int Rapeseed Cong. 1991;2:442-7.

82. Ciurescu G. Efficiency of soybean meal replacement by rapeseed meal and/ or canola seeds in commercial layer diets. Archiva Zootechnica. 2009;12:27-33.

83. Salmon RE, Gardiner EE, Klein KK, Larmond E. Effect of canola (low glucosinolate rapeseed) meal, protein and nutrient density on performance, carcass grade, and meat yield and of canola meal on sensory quality of broilers. Poult Sci. 1981;60:2519-28.

84. Lee KH, Olomu JM, Sim JS. Live performance, carcass yield, protein and energy retention of broiler chickens fed canola and flax full-fat seeds and the restored mixtures of meal and oil. Can J Anim Sci. 1991;71:897-903.

85. Jia W, Slominski BA, Bruce HL, Blank G, Crow G, Jones O. Effects of diet type and enzyme addition on growth performance and gut health of broiler chickens during subclinical Clostridium perfringens challenge. Poult Sci. 2009:88:132-40.

86. Silva SD, Hesselman K, Aman P. Effects of water and beta-glucanase treatment on non-starch polysaccharides in endosperm of low and high viscous barley. Swed J Agric Res. 1983;13:211-9.
87. Alloui MN, Szczurek W, Wiliczkiewicz SS. The usefulness of prebiotics and probiotics in modern poultry nutrition: review. Ann Anim Sci. 2013;13(1):17-32.

88. Bedford M, Apajalahti J. Microbial interactions in the response to exogenous enzyme utilization. Wallingford: CABI Publishing; 2001. p. 299-314.

89. Slominski BA. Recent advances in research on enzymes for poultry diets. Poult Sci. 2011;90:2013-23.

90. Jia W, Slominski BA, Guenter W, Humphreys A, Jones O. The effect of enzyme supplementation on egg production parameters and omega-3 fatty acid deposition in laying hens fed Flaxseed and Canola Seed. Poult Sci. 2008;87(10):2005-14.

91. Slominski BA. Enzyme hydrolysis products and yeast-derived products as prebiotics and natural alternatives to antibiotic growth promoters, Department of Animal Science, University of Manitoba. 2014. http://en.engormix.com/MApoultry-industry/nutrition/articles/enzyme-hydrolysisproducts-yeast-t3043/141p0.htm. Accessed 10 Jul 2014.

92. Sugiharto S. Role of nutraceuticals in gut health and growth performance of poultry. J Saudi Soc Agric Sci. 2014. http://dx.doi.org/10.1016/j.jssas.2014.06.001.

\section{Submit your next manuscript to BioMed Central and take full advantage of:}

- Convenient online submission

- Thorough peer review

- No space constraints or color figure charges

- Immediate publication on acceptance

- Inclusion in PubMed, CAS, Scopus and Google Scholar

- Research which is freely available for redistribution 